\title{
AGROECOLOGY COMMUNITY AND ECOLOGY OF KNOWLEDGE: A TRAINING EXPERIENCE BASED ON THE PARTNERSHIP BETWEEN QUILOMBO, PASTORAL LAND COMMISSION AND UNIVERSITY
}

\section{COMUNIDADE AGROECOLÓGICA E ECOLOGIA DOS SABERES: UMA EXPERIÊNCIA DE FORMAÇÃO BASEADA NA PARCERIA ENTRE QUILOMBO, COMISSÃO PASTORAL DA TERRA E UNIVERSIDADE}

\author{
Dernival V. Ramos ${ }^{1}$, Flora Bittencourt ${ }^{1,2}$, Felipe E. L. Oliveira ${ }^{1,3}$, Kênia G. Costa ${ }^{1}$, \\ Vinicius G. Aguiar ${ }^{1}$, Raimundo Cantuário C. dos Reis ${ }^{1,4}$ \\ ${ }^{1}$ Research and Extension Core in Agroecological Knowledge and Practices (Neuza), \\ Federal University of Tocantins (UFT). Araguaína, Tocantins, Brazil. \\ ${ }^{2}$ Amazon Institute of Family Agriculture (INEAF), Federal University of Pará. Belém, \\ Pará, Brazil. \\ ${ }^{3}$ Pastoral Land Commission (CPT). Araguaína, Tocantins, Brazil. \\ 4 Quilombola Leardship of Quilombo of Grotão \\ dernivaljunior@gmail.com
}

\begin{abstract}
Resumo: A formação da Comunidade Agroecológica entre NEUZA-UFT, a Comissão Pastoral da Terra (CPT) e a Comunidade Quilombola do Grotão foi pensada como situação gnosiológica e, por isso, momento formador baseado na ecologia dos saberes. Coordenada por Pedro Ribeiro da equipe do NEUZA-UFT/CPT e agente Pastoral da CPT e por Raimundo Cantuario Camilo dos Reis, liderança quilombola da comunidade Grotão, contou com a participação de professores e estudantes da Universidade Federal do Tocantins, agentes pastorais e jovens quilombolas. Iniciou-se ali o processo de formação da Comunidade, a partir da articulação diferentes sujeitos universitários, agentes pastorais e comunitários em torno da discussão, promoção e prática do espaço-tempo agroecológico.
\end{abstract}

Palavras-chave: Agroecologia; Ecologia dos Saberes; Experiência Formadora

Abstract: The formation of the Agroecological Community among NEUZAUFT, the Pastoral Land Commission (CPT), and the Quilombo Grotão was conceived as a gnoseological situation and for that, it is a formative moment based on the ecology of knowledge. It is coordinated by Pedro Ribeiro of the NEUZA-UFT/CPT team, the Pastoral Agent of the Pastoral Land Commission 
(CPT) and by Raimundo Cantuario Camilo dos Reis, quilombola leadership of the Grotão Community. It had the participation of professors and students from the Federal University of Tocantins, pastoral workers and young quilombolas. The process of formation of the Community began there, starting from the articulation of different subjects, university students, pastoral and community agents around the discussion, promotion and practice of the agroecological space-time.

Keywords: Agroecology; Ecology of Knowledge; Formative Experience

\section{Introduction}

Agroecology is a movement to construct the ecology of knowledge and intercultural practices because "it seeks the convergence between multiple knowledge"(Santos, 2010a, p.161). It is based on the recognition of the epistemic diversity of the world and the epistemologies of the South as historically marginalized knowledge, but they arise as a solution possibility to the problems created by the dominant epistemologies (Santos, 2010a).

Thus, the spaces-times of Agroecology organized from the non-hierarchical dialogue among knowledge and subjects of diverse epistemic communities, the university, the social movements and traditional communities become effective as a gnoseological situation: "one in which cognitive act does not end in the object cognizable because it communicates to other equally cognizant subjects" (Freire, 1983) inhabited by the one who teaches, learns and in learning, teaches; the one who builds new knowledge from the true dialogue.

This text describes a formative experience in Agroecology constructed by the NEUZA-UFT team, agents of Pastoral Land Commission and by members of the Quilombo of Grotão as a collaborative moment. The aim was to give the first step for the construction of the Agroecological Community involving the university, the Pastoral Land Commission and Quilombo of Grotão.

\section{Development}

The Quilombo Grotão is formed by nineteen families. The leaderships are seeking to rescue and strengthen their culture. Consequently, they constantly recall the impressions of the traditional festivals, such as the Feast of Saint Benedict, the 
Feast of the Divine, Saint John, Saint Peter, Saint Lazarus and the traditional dance of the "Salambisco". There is also an effort to maintain traditional material production. Artifacts such as wooden spoon, tapiti (a device for pressing cassava), fan, pestle, balaio, basket and broom produced with bacaba's leaf (Oenocarpus bacaba) a Brazilian palm tree, clay oven, bed of embira (Mauritia flexuosa) another Brazilian palm tree, coifo (a little basket), bodoque (a device to hunt birds and collect fruits in tall trees), clay pot traditional in the community are results of its relation with the local environment (Almeida, 2011).

In this way, given the characteristics and singularities of the community in question, NEUZA-UFT is attentive to the dynamics and complexities involved in the territory and the daily life of the community as well as its traditional agroecological practices and knowledge. Thus, the first agroecological activity developed by this group took into account the importance of members of the Community participation, as holders of traditional knowledge, shared and experienced by the Core, thus strengthening interculturality and the ecology of knowledge through the protagonism and empowerment of non-academic knowledge. For the subjects involved, this experience potentiates the construction of a decolonial attitude (Maldonado-Torres, 2016) enhances the deconstruction of epistemic hierarchies and reinforces the legitimacy of the epistemologies of the South.

According to Josso (2004), the formation occurs when the subjects mobilize their own senses and knowledge from inside themselves and were positioned by the diverse experiences throughout life.

This movement of formation produces new knowledge, perceptions and positions. As a hypothesis, the search for construction of a gnoseological situation allowed an emergence of ecology of knowledge: from the conception to the realization of the ecology of the epistemic knowledge and diversity, with theoretical-practical compasses. Therefore, the shared knowledge will be the basis for the construction of the community of agroecological practice of intercultural basis.

As a pilot experiment, the process of formation of the agro-ecology community began with the articulation of different university and communitarian subjects around the discussion, promotion and practice as an agroecological space-time. In practical terms, the stage described in this paper occurred on September 22nd, 2018 in Dona Olinda Farmstead, located in Araguaína, Tocantins. It was the first practical-formative 
activity articulated among NEUZA-UFT Research and Extension Core on Agroecological Knowledge and Practices and the Quilombo Grotão, which is located in Filadélfia, Tocantins.

Coordinated by Pedro Ribeiro and Raimundo, the quilombola leadership, the experiment had the following sequence: a) to encase the hoes and scythes to be used in the experiment; b) to visit the forest and understand its environmental dynamics; c) to drill the area and to plant; d) to collect soil for laboratory analysis and e) to discuss about the whole experience.

The first activity of the day was the field work equipment preparation. The participants learned the technique of mashing and/or making the hoe and hoe handle guided by Raimundo. In the morning, we learned how to choose the right wood, size, thickness, thinning as the hoe arch, the center of the cable to fit it, the correct hoe angle in relation to the cable and the movements to grass remove.

In order to understand the dynamics of the natural factors and the morphoclimatic conditions of the locality, Pedro taught us the natural fertilization techniques and how to analyze the basic soil conditions, the main aspects of humus, and the differences between the amounts of organic matter on soils. Inside the forest, we observed the vegetation cover, the layer of decomposition of leaves and roots and its importance for the maintenance of the whole vegetation. Such elements as water, oxygen, vegetation cover, microorganisms, and minerals create favorable conditions for the proliferation of microorganisms that contribute to the organic matter decomposition, manuring and fertilizing the soil.

Pedro showed us the distinction between the soil removed from the forest and the soil removed from the area where the agroecological experiment would be developed. The soils are very different. In the first one, the organic matter predominated and the sand percentage was much smaller than the second one. It was possible to visualize the lack of organic matter and sand predominance in non-forestry area.

In addition, during the forest walk, we discuss the successional process and the forest cycle, understanding that agroforestry practices are in accordance with this important phenomenon.

Then, we were separated in groups and began to cut the vegetation on the pilot experience area, about $800 \mathrm{~m} 2$. We finished the whole process of pruning in about an 
hour and a half. Then, one of the groups made the pits for the other to sow the seeds. This step lasted about two hours. The plants selected for planting were mucuna preta (Mucuna pruriens) and andu beans (Cajanus cajan). The mucuna preta is a specie of the Fabaceae Family (legume) annual and with habit of undetermined growth (climbing), very rustic species. It is indicated for the recovery degraded soils as an excellent option for green fertilization and nitrogen fixation. The andu beans can be used for green manure production to recover the soil, since it fixes a high amount of nitrogen (EMBRAPA, 2004). As its roots are long and deep, and because of its shrubby shade, it maintains moisture for longer and allows rainwater to more easily penetrate the soil.

This pilot experiment was carried out following the quilombola lunar calendar based on the principles of the ecology of knowledge. For this, the branch plants should be planted until 03 days before the full moon. Therefore, mucuna and andu must follow this chronology. This was one of the reasons for NEUZA-UFT's choice to carry out in a different space of the community territory as a pilot experience. For that, it would be necessary to wait the following month for effective planting in the territory of the quilombo.

The soil was collected to characterize the fertility of the area through the amount of nutrients, composition, and other elements through a fraction of the soil.

The apparently sandy morphology was revealed in the soil samples. The proposal is that vegetable fertilizers help with a higher concentration of organic matter and consequently provide more nutrients in the soil.

In the last step, we did a round table evaluating the experience. This conversation was thought of as a catalyst for the ecology of knowledge, when we systematized new knowledge from the dialect, of non-hierarchical practice and elaboration between subjects and episteme. From a didactic-pedagogical point of view there was the production of a dialogue between traditional, militant and academic knowledge.

Pedro and Raimundo answered the questions about the use of mucuna and andu beans and clarified the doubts about the use of these species and the expected results. Raimundo described and explained the lunar calendar and its influences on planting certain plants such as beans, corn, cassava, for example. 
Pedro explained how we can identify the presence of organic matter in the soil with simple experiment using pet bottles. For this, farm soil samples from different areas were mixed with water and deposited in different pet bottles. After a fast period of sedimentation, it was possible to observe the organic matter in the surface and the solids of greater volume, deposited in the bottom.

As the final moment of the conversation, we watched some videos with the presentation of successful use of the green manure technique experiences with the use of mucuna and andu beans that contributed to the discussion about the use of green manuring in the soils of the north central region of Tocantins.

\section{Discussion and final words}

As a movement to build the ecology of knowledge and intercultural practices, the construction of agroecological knowledge always occurs within agroecological communities organized from the non-hierarchical dialogue between knowledge and subjects of diverse epistemic communities.

The members of the agroecological communities should seek a decolonial attitude and this pilot formative experience moment was planned from the development of attitudes of de-racialization, depatrialization, decolonization and de-marketization (Maldonado-Torres, 2016). In order to do that, the experience instituted a decolonial space-time in which the various subjects confronted these hierarchies as a way of constructing the experience and achieving the formative goals.

The socialization of knowledge and training in the practice of academic and community subjects should potentiate the existence of these four elements (deracialization, depatrialization, decolonization and de-quantization) of domination built by the modern colonial system.

The traditional knowledge and practices are under strong industrial agriculture pressure. The State of Tocantins, especially in the north-central region, traditionally dominated by livestock, has become a frontier for new industrial crops - such as eucalyptus (Eucalyptus sp) and soybeans (Glycine max) - as well as site for the installation of large development projects and infrastructure - railways, waterways and hydroelectric power plants. The expansion of these initiatives, which increase land tenure and tend to increase violence in the countryside, become a threat to the way of 
life of various indigenous groups, quilombola community and traditional peasants, who live in the region and manifest themselves as a moment of colonization.

Recent researches recognize the deep ecological knowledge that the communities have and their importance in biodiversity conservation, arguing that in fact, biodiversity is a socio-diversity. After a voluminous archaeological research, Levis et al. (2017) conclude that the distribution of a large part of the Amazonian species is the result of the forest management carried out by the indigenous groups. To use another term, the Amazon has always been an agroforestry.

Historically, these groups are producers through their agricultural production systems of biodiversity. The field surveys of Oliveira and Anjos (2016) indicate the presence of these knowledge and agroforestry systems among the traditional peasants of the north of the region of Tocantins, an area of activity of the Neuza-UFT. The APA/TO (Alternatives for Small Agriculture of Tocantins) has acted through the Network Agroecological Network Project, mapping traditional agroecological knowledge in the Bico do Papagaio Region and enhancing them through the promotion of agroecological experiences and practices. This project corroborates the conception of importance of transdiciplinarity in agroforestry promotion presented by Wezel et al. (2009) and Altieri (2012). It seems to confirm the initial hypothesis of NEUZA-UFT, which is that Agroecology will always advance as an ecology of knowledge and as an intercultural and inter epistemic Community.

\section{References}

Almeida, R. A. (2011). Laudo Antropológico de Reconhecimento e Delimitação do Território da Comunidade Quilombola do Grotão Filadélfia-Tocantins. Instituto Nacional de Colonização e Reforma Agrária, Coordenação Geral de Regularização de Territórios Quilombolas-DFQ, Superintendência Regional do INCRA-SR 26. Brasília-DF.

Altieri, Miguel (2012). Agroecologia: bases científicas para uma agricultura sustentável. São Paulo/ Rio de Janeiro: Expressão Popular.

EMBRAPA. Ministério da Agricultura, Pecuária e Abastecimento. Cartilha ABC da Agricultura Familiar (2004). Feijão-ghandu: uma boa opção para a sua alimentação. Brasília, DF: Autor. 
Filizola, H. F. (2006). Manual de procedimentos de coleta de amostras em áreas agrícolas para análise da qualidade ambiental: solo, água e sedimentos. Jaguariúna: Embrapa Meio Ambiente.

Freire, P. (1983). Extensão ou comunicação. 7. ed. Rio de Janeiro: Paz e Terra.

Josso, M. C. (2004). Experiência de vida e formação. São Paulo: Cortez.

Levis, C. et al. (2017). Persistent effects of pre-Columbian plant domestication on Amazonian forest composition. Science, 355, 925-931.

Maldonado-Torres, N. (2016). Transdisciplinaridade e decolonialidade. Revista Sociedade e Estado, 31, 75-97.

Oliveira, F; Anjos, E. (2016). Cotidiano camponês: da tradicionalidade camponesa a agroecologia. Caderno de Agroecologia: Alternativas para o Bem Viver, 1, 18-22.

Santos, B. de S. (2010a). Epistemologias do Sul. São Paulo: Cortez.

Santos, B. de S. (2010b). A gramática do tempo. Por uma nova cultura política. São Paulo: Cortez.

Wezel, A. et al. (2009). Agroecology as a science, a movement and a practice. A review. Agronomy for Sustainable Development, 29 (4), 2-13.

\section{Acknowledgments:}

The authors acknowledge the valuable collaboration and technical assistance from Quilombo of Grotão e Pastoral Land Commission (CPT). Araguaína, Tocantins, Brazil.

\section{Funding:}

This publication was funded by CNPq.

\section{Declaration on conflicts of interests:}

The authors declare that the research was conducted in the absence of any commercial or financial relationships that could be construed as a potential conflict of interest. 